\title{
STUDY OF THE CHANGE OF THE SPECIALISTS' ISOLATIVE GARMENT PROPERTIES AGAINST THE EFFECTS OF PEROXIDE DECONTAMINATION MIXTURE
}

\author{
Zdeněk MELICHAŘíK*, Pavel OTŘíSAL ** \\ *Faculty of Physical Culture, Palacký University at Olomouc, Czech Republic \\ **NBC Defence Institute of the University of Defence at Brno, Czech Republic \\ zdenek.melicharik@upol.cz, pavel.otrisal@unob.cz
}

\begin{abstract}
The influence of the peroxide decontamination mixture on the barrier polymeric material used for the construction of the anti-gas protective garment OPCH-05 has been study. This kind of mixture is used with the help of the decontamination vehicle ACHR-90 and its EDS mixture. The both soldiers and operators of the ACHR-90 or the EDS mixture can be in a direct contact with spattering decontamination mixture that can cause significant damages of the anti-gas protective garment OPCH-05. For evaluation of protective properties and their potential changes the MIKROTEST method and methodology has been used. This paper is another publication which deals with the influences of decontamination mixtures introduced in the Czech Armed Forces Chemical Corps armament on the barrier material composed of the butyl-rubber polymeric mixture in combination with the polyamide textile.
\end{abstract}

Keywords: Isobutylen-isoprene rubber, peroxide decontamination mixture, breakthrough time, OPCH-05, sulfur mustard, MIKROTEST

\section{Introduction}

The Czech Armed Forces (CAF) Chemical Corps (CCs) tasks in relation to the North Atlantic Treaty Organization (hereinafter "NATO", "Alliance") coming out from the Czech Republic's (CR) civilian and military documents. The CAF CCs specialists are assigned to Alliance task forces structures to carry out specific and specialized tasks in the area of the chemical support and chemical, biological, radiological and nuclear (CBRN) defence included protection against the harmful and dangerous substances such as weapons of mass destruction (WMD) and toxic industrial materials (TIM). These tasks are clearly aimed at minimizing the effects WMD and TIM on the CAF and NATO forces. One of the long-listed security threats is the possibility of TIM employment in military operations. For this reason, it is necessary to study the protective properties of individual protective equipment (IPE) in order to obtain information on their current protective properties. This information can then be used to specify new system and technical requirements for new IPE that can be constructed using new materials and advanced technologies.

The real existence and possibility of the use of chemical weapons and the military use of TIM properties by the enemy in military operations conducted in various countries of the world lead scientists and specialists to develop methods to improve the insulation protection of the CAF $\mathrm{CCs}$ specialists, especially in relation to toxic 
industrial chemicals (TIC). These measurements are always crucial for evaluation of current and new barrier materials which can be potentially employed for enhancing a level of the physical protection in all kinds of military operations [1-3]. The effort of scientific workers and organizations must be also conducted by the permanent ambition to keep not only military health norms but norms valid in a civilian area. From the historical aspects of military perception of operations come out some new approaches that are challenges for soldiers, doctors and other specialists who are responsible for saving professionals' lives. Entirely different approaches to barrier material testing from the time before the CR "velvet revolutions" led to the improvement of testing methods and subsequently to the new possibilities of achieved data evaluation. On the other hand, some testing methods which are designated for testing the chemical resistivity against chemical warfare agents (CWA) are usable in current time. These methods are principally the same; however, their using and obtained data is rather wide with the possibility to interpret it in different way.

\section{Theoretical part}

Specialists of the CAF CCs and Fire Rescue Brigades use insulating means of body surface protection within fulfillment of the most complex and specific tasks of chemical support, CBRN Defence and civilian consequence management connected with TIM in their professional activity [4]. Protective properties determining the resistance of the garment against the permeation of toxic substances are characterized by the breakthrough time (BT) in the CAF environment. In the case of an insulating protective garment, BT is considered to be the time for which the barrier material provides the full chemical protection against a liquid phase of CWA. This time can be defined in many ways. The most employment definition is connected only with CWA and it is defined as a period of time from the beginning of a drop application to the face of the tested material to its permeation in the form of vapor on the reverse side in an amount corresponding to the sensitivity of the detection reaction, preferably in the threshold amount $[5,6]$. This definition touches the method that has been used for the measurements presented in this paper. It should be regularly added that nowadays, there are other definitions which work with the sensitivity of chemical reactions, sensors and so on. From these reasons some new values have been accepted within scientific community. They must balance all inputs that are not the same in the scope of all established and used methods and methodologies. The brand-new terms such as permeation rate, permeation mass, lagtime and some others help to define permeation results in more precise way and, furthermore, in the same values that are understandable for researchers, teachers and for all who describe protective properties of current and newly develop and potential barrier materials.

One of the areas that the University of Defence NBC Defence Institute has been working on over a long period of time is the testing of butyl-rubber polymeric mixture used in the manufacture of insulating protective garments against the permeation of CWA and TIC. It is already evident from the previously published reports that the resistance against chemical compounds of the used material expressed by BT has its important limitations. This limitation increases precisely in relation to the liquid TIC, which are components of the established decontamination mixtures in the CAF $[7,8]$. Because these problems have not been solved in a comprehensive way, experimental work has been launched to clearly define the dangerous impacts of the liquid form of decontamination mixtures on $\mathrm{OPCH}-05$ anti-gas protective clothing. Within fulfilling the CAF CCs specific tasks specialist, it can be reasonably 
assumed that the contact of decontamination mixtures and anti-gas protective clothing $\mathrm{OPCH}-05$ in the framework of decontamination can occur. Thus, contact with the consequence of possible influence on the structure of the insulating protective film formed by butylrubber may be mentioned. The butyl rubber, sometimes called only as butyl This is the synthetic rubber copolymer of isobutylene with isoprene. This kind of rubber has a lot of excellent properties which designated this material for a lot of applications not only in civilian but also in military areas. He is a typical representative of non-polar polymeric substances. From that reason we can expect some specific properties that can significantly limits the employment of this barrier material. Macromolecules of isobutylene-isoprene rubber (IIR) additionally contain cyclic repeating unsaturated double bonds in their structure. These bonds can be attacked by the atoms of the decontamination mixture agents and become reaction sites that lead to the destruction of polymer structures.

The MIKROTEST method and methodology were used to determine the effects of decontamination mixtures and to study destructive effects on the insulating protective foil. The MIKROTEST method and subsequently methodology was discovered based on Russian knowledge at the Military Research institute, State enterprise (former Military Technical Research Institute of Protection) in Brno [9]. This colorimetric method is traditionally used not only within the CAF CCs but also in the framework of the Fire Rescue Brigade Chemical Service. For the assessment of the barrier properties of considered tested materials the sulfur mustard, [HD, bis(2-chloroethyl) sulfide] is used.

The MIKROTEST method is based on the reaction of mustard with chloroamide
[CNITI-8; $N$-chloro- $N$-(2-tolyl) benzamide]. The reaction liberates hydrogen chloride which converts the alkaline form of an acidbase indicator to the acidic one (here the red form of Kongo Red to the blue form) using azo-hydrazone tautomerism [10].

This CWA belongs to the persistent one. Its biggest advantage is a relatively small molecule with the relatively small molar volume $[11,12]$. This CWA is also very friendly from manipulation because of the fact it is less toxic than representatives of CWA of the nerve agent type. This CWA is also typical by its simple chemical structure and quite good availability. Moreover, sulfur mustard can be simply replaced with 1,6-dichlorofexane as a simulant for the purposes of training practical aspects of permeation through barrier materials with no need to keep strong health and organizational regulations [13]. Nonetheless, for the purposes of this research and presented results HD has been used.

\section{Used chemicals and materials}

The part dealing with used chemicals and material respects similar regulations presented in earlier publications within KBO conferences [14, 15].

\subsection{Used chemicals}

The peroxide decontamination mixture (PDM), the basic data of which is given in Table 1, was used to study the destructive effects on the insulating protective film. The chemical alkaline hydrogen peroxide is used for chemical degradation of CWA. It is prepared immediately before using the mixture. The nucleophilic activity of a hydroxyperoxide anion is used to itself decontamination. This process produces a yellow chemical which represents the 3methyl-4-nitrophenolate anion. The selected properties of components that are parts of the PDS and the used chemicals are summarized in Table 2. 
Table 1 Basic data related to PDM

\begin{tabular}{|l|l|c|c|}
\hline Mixture & \multicolumn{1}{|c|}{ Composition } & $\begin{array}{c}\text { Time of } \\
\text { application } \\
{[\mathbf{m i n}]}\end{array}$ & $\begin{array}{c}\text { Consumpti } \\
\text { on } \\
{\left[\mathbf{d m}^{\mathbf{3}} \cdot \mathbf{m}^{-2}\right]}\end{array}$ \\
\hline PDM & $\begin{array}{l}\text { 30 parts by volume of 30\% hydrogen peroxide } \\
\text { and 70 parts by volume of the organic peroxide } \\
\text { component }\end{array}$ & 30 & 0,5 \\
\hline
\end{tabular}

Table 2 Used chemicals specification

\begin{tabular}{|l|c|l|}
\hline \multicolumn{1}{|c|}{ Name of the chemical } & $\begin{array}{c}\text { Specification, } \\
\text { clearness }\end{array}$ & \multicolumn{1}{c|}{ Producer (provider) } \\
\hline bis(2-chloroethyl) sulfide \\
sulfur mustard & $\begin{array}{c}92,7 \% \text { distilled } \\
\text { sulfur mustard } \\
\text { Methylcellosolve, n- } \\
\text { butyl alcohol, } \\
\text { ethylene glycol, } \\
\text { Organic component PDM }\end{array}$ & $\begin{array}{l}\text { Military repair facility 072, Zemianské } \\
\text { Kostol'any, Slovakia }\end{array}$ \\
& $\begin{array}{c}\text { hydroxide, sodium } \\
\text { molybdate }\end{array}$ & Military repair facility 026, Sternberk, CR \\
\hline
\end{tabular}

\subsection{Used material}

The IIR is the basic protective material used for final construction of the anti-gas protective garment $\mathrm{OPCH}-05$. Summarizing information is in the table 3 .

Table 3 Information concerning the anti-gas protective garment $\mathrm{OPCH}-05$

\begin{tabular}{|l|l|}
\hline Marking of the barrier material & Protective textile TP-RUB-001-06 \\
\hline $\begin{array}{l}\text { Type of the carrier of the polymeric barrier } \\
\text { material }\end{array}$ & Polyamide textile \\
\hline Way of coating & both-side (rolling machine) \\
\hline $\begin{array}{l}\text { Producer of the constructional barrier } \\
\text { material }\end{array}$ & $\begin{array}{l}\text { Rubena, public limited corporation, Hradec } \\
\text { Králové, CR }\end{array}$ \\
\hline Producer of the final product & ECOPROTECT, Ltd, Zlín, CR \\
\hline
\end{tabular}

Samples of the tested material have been made in the same way for the whole test. The material and aids that have been used are as follows:

- the biological incubator FRIOCELL (Brněnská medicínská technika, Brno, $\mathrm{CR}$ );

- the cutter of samples (Marbach, limited company, Brno, CR);

- the hydraulic press (Polymertest, limited company, Zlín, CR);

- the quick thickness meter Mitutoyo, type 542-401 (Mitutoyo Corporation, Japan);

- the plastic a Pasteur's pipette - volume 3 $\mathrm{ml}$ (Merci, CR);
- the school paintbrush - hardness No 4 (Spokar, Spojené kartáčovny, Inc. Pelhřimov, CR);

- the USB microscope DigiMicro 2.0 Scale (Drahtlose Nachrichtentechnik, GmbH, Ditzenbach, Germany).

\section{Working procedures}

Used PDM has been prepared in the laboratory conditions without the employment of the EDS mixture. The whole volume of the prepared PDM has reacted very intensively because of hydrogen peroxide presence. Due to this fact mixing speediness has been limited in order to prevent the PDM spilled out from 
the beaker. It should be stress that mixing components is dynamically done without the crew intervention in real conditions.

The original footage of the tested material has been cut on stripes, width $6.5 \mathrm{~cm}$. These stripes have been standardized in the FRIOCELL incubator for 120 minutes in order to organic volatile agents' evaporation. After this time stripes have been left for 180 minutes within the laboratory temperature for their stabilization. Stripes of the tested material have been cut into the squares (size $6.5 \mathrm{x}$ $6.5 \mathrm{~cm})$. For this purpose, the cutter and the hydraulic press have been employed. Similar samples have been made from material containing the seam. Samples that have been prepared for as a reserve have been put into the desiccator. Indication of the tested material samples served to their clear identification and easier description. The thickness of each sample has been measured approximately in the middle of the square. Groups of samples containing ten samples have been formed in accordance with their thickness. Ethanol was used for wiping samples of the test material. Two milliliters of the decontamination mixture have been dosed to the middle of each sample within common laboratory temperature. The volume of the mixture has been immediately sliced with circle movements of the school paintbrush on the whole area of the sample $\left(42 \mathrm{~cm}^{2}\right)$. The operation time of the PDM was 15 minutes and then samples were dried. Moistening samples with the PDM have been performed to achieve the state to be constantly damp overall their surface for the whole test. Each decontamination cycle has been performed after rinsing samples in distilled water after their contamination with PDM and drying on filtration paper for 180 minutes. After this time new contamination cycle with PDM has started. The number of contaminated groups of samples was limited. Two groups of samples were prepared in one day using this procedure. For the practical assessment of the PDM influences on the test material ten decontamination cycles were performed. The time/samples consumption for the whole test was five days/one hundred.

\section{Results of tests and discussion}

Samples showed a standard light green color at the start of the test. In the case of samples cut off from that part of the antigas protective garment containing a seam, a typical light green to gray-green color appeared at the beginning of the measurement. This coloration was also considered as standard (Figure 1). In Figure 1 , on the left, a texture of the polyamide carrier fabric is visible. The visible texture suggests a lower thickness of the butylrubber coating than on the seam sample at the seam location. It is generally assumed that the seam can cause leakage of the garment and it is therefore provided with a stronger coating to prevent permeation of the chemicals by a relatively inhomogeneous bonding of two or more parts of the anti-gas protective garment. 


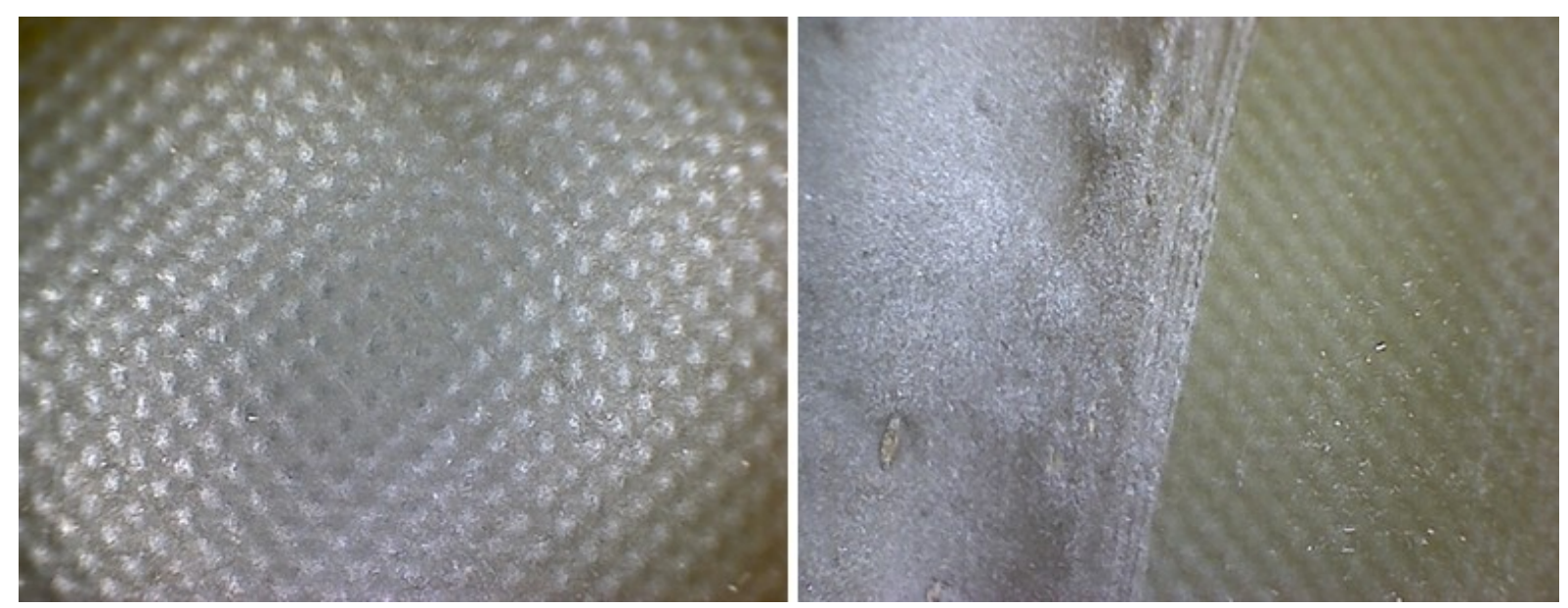

Figure 1: The OPCH-05 anti-gas protective garment film at the beginning of the test (right sample containing the seam)

The PDM was applied to the samples of the tested insulating film with the above described procedure. The PDM time of operation has been selected for 30 minutes. After the third decontamination cycle, partial destruction effects were observed in the space between the tested material and the seam that was coated. It was apparently due to the presence of the organic component of the PDM. The organic component which is not homogeneously
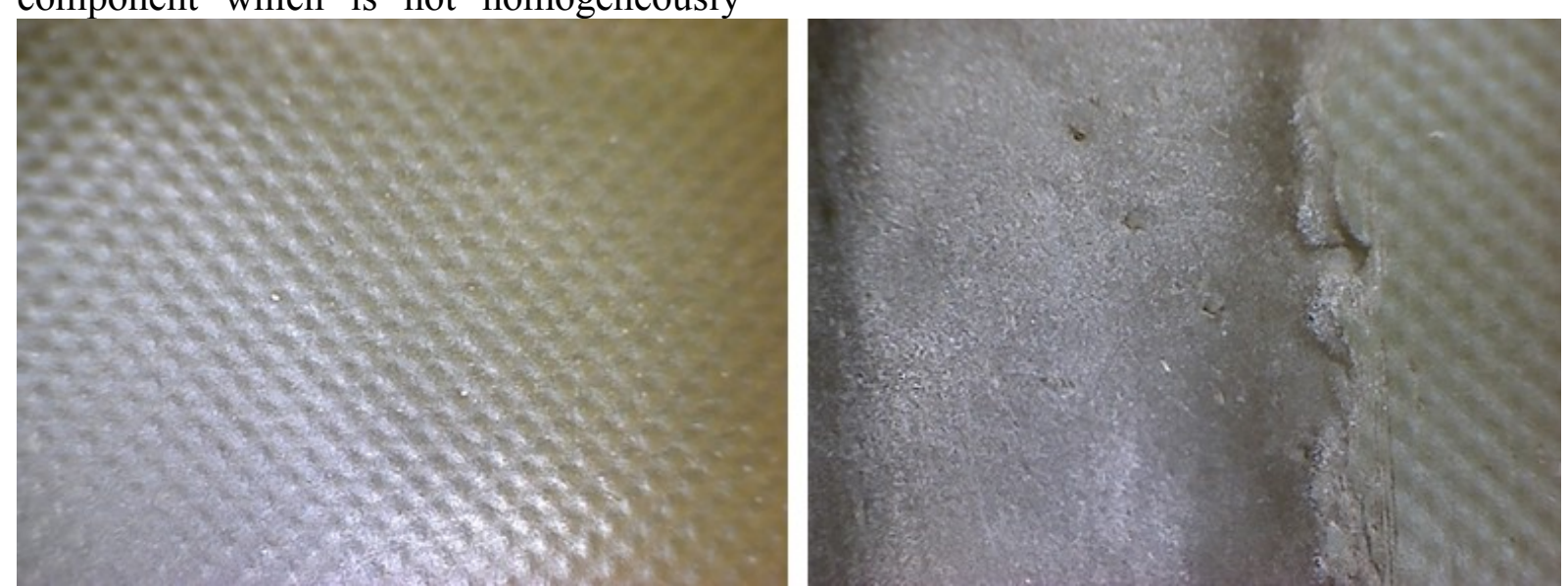

dissolved in the PDM and forms a substantially colloidal mixture causes the swelling of the tested material. The seam in the place of the connection with the seam and the standard material, thus at the place of the thickness transition, changes its properties, expands and the polymer deposit is partially separated. This irreversible change is visible especially on the right picture in Figure 2.

Figure 2: The OPCH-05 anti-gas protective film after three cycles of PDM contamination (left fabric, right seam after PDM effect)

After the $4^{\text {th }}$ to $6^{\text {th }}$ decontamination cycle, no further deepening of the destructive effects on the surface of the tested insulated film was observed. It can be stated that, based on pictures taken using the USB 

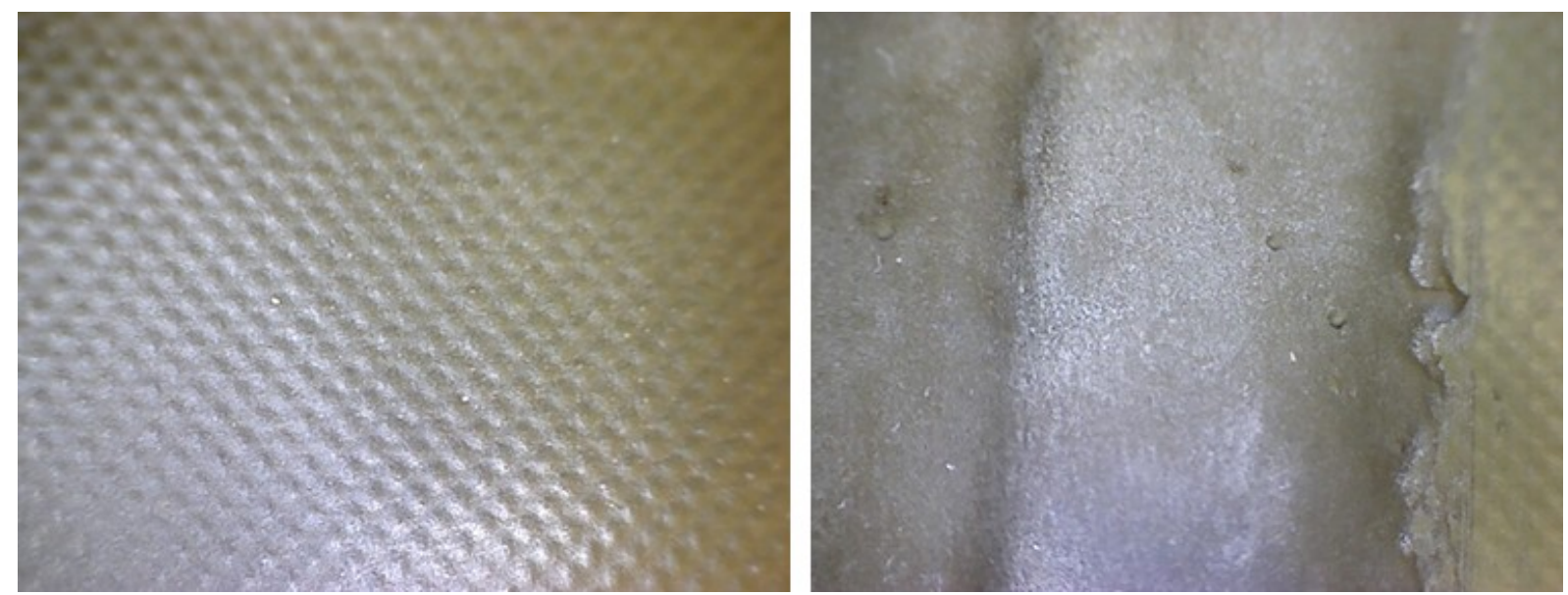

Figure 3: The OPCH-05 anti-gas protective film after six cycles of PDM contamination (left fabric, right seam after PDM effect)

After the $7^{\text {th }}$ to $10^{\text {th }}$ decontamination cycle of the sample, the tested insulating film showed a minor surface disturbance. It could be caused by most likely due to the mechanical action of the brush when depositing the decontamination mixture, especially on the surface of the tested seamless insulating film, as seen in Figure 4. The tested material, after the multiple effect of PDM, probably increased its elasticity and softened abrasion, indicating a tiny change in BT.
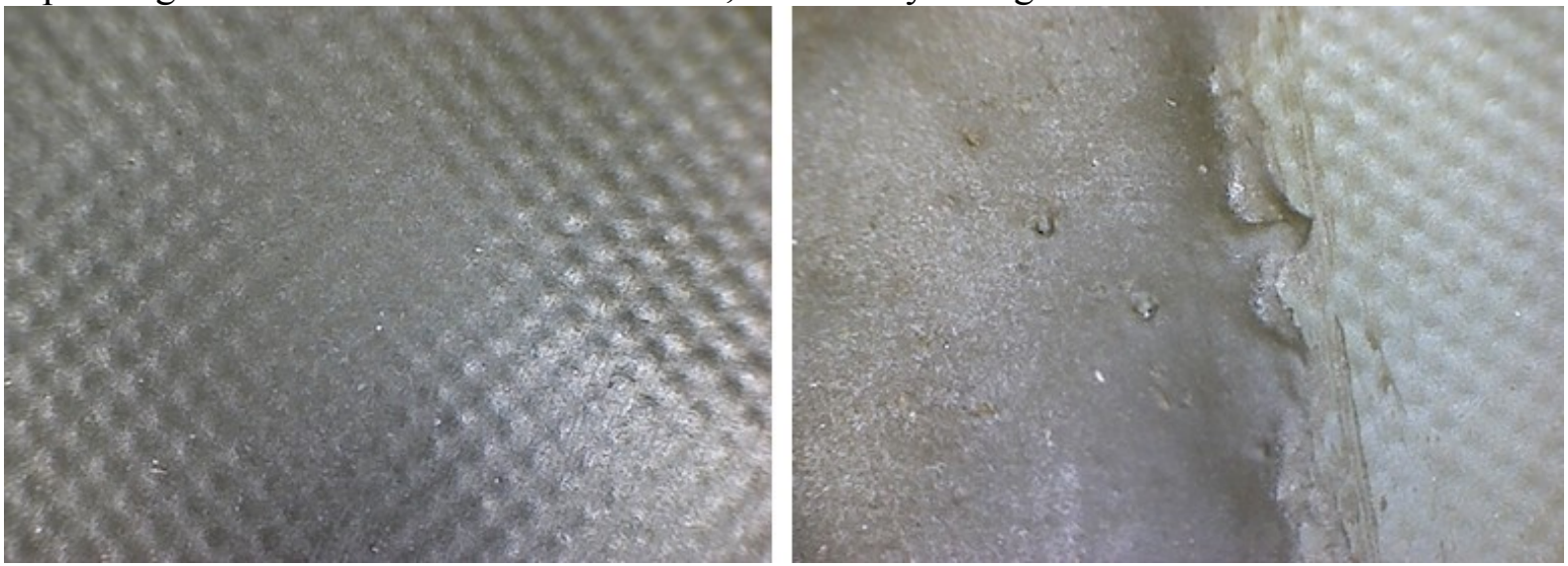

Figure 4: The OPCH-05 anti-gas protective film after ten cycles of PDM contamination (left fabric, right seam after decontamination mixture affection)

The minimal effect of the PDM on the protective properties of the tested constructional material of the insulating foil was demonstrated even after the test with the MIKROTEST method. The rate of BT dependence on the number of decontamination cycles is shown in Figure 5. When comparing the BT value of a pure sample not tested (BT value 399 minutes), the BT values after the 1st to 10th decontamination cycle ranged from 390 to 420 minutes. Based on the linear regression analysis, the practically unchanged course of BT values can be observed in relation to the number of performed decontamination cycles. Minimal deviations in BT values and chemical resistance of tested insulating film against sulfur mustard permeation is probably due to the strongly non-polar character of the used butyl-rubber. It can be stated that the protective properties of the tested insulating protective film do not change significantly with the effect of PDM. 


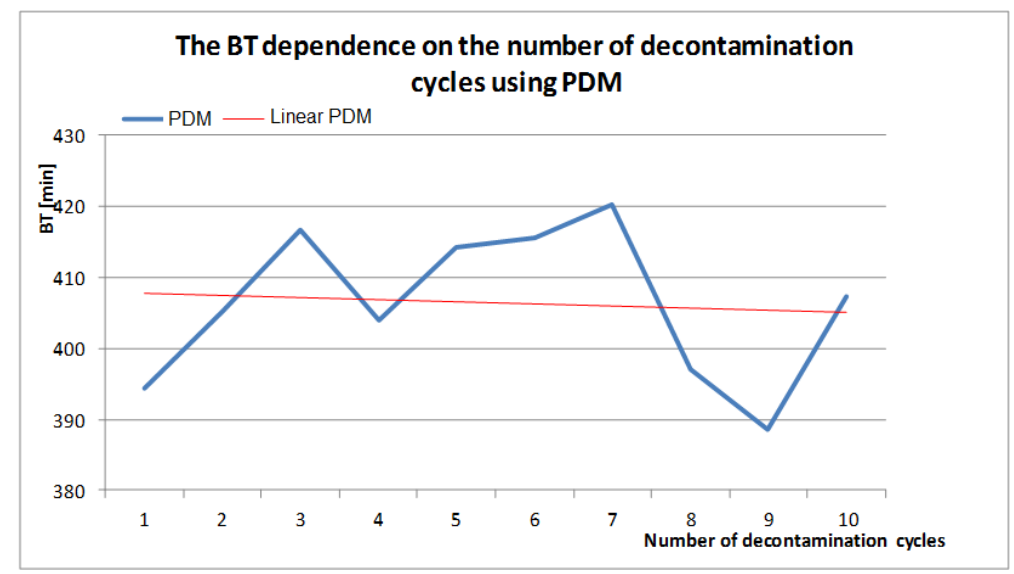

Figure 5: The rate of the BT change of the tested material of the OPCH-05 anti-gas protective film after repeated decontamination with the PDM

\section{Conclusion}

The butyl-rubber is the basic polymeric material in the production of insulating protective clothing for $\mathrm{CAF} \mathrm{CCs}$ specialists. It is characterized by its nonpolar properties, high resistance to water, acids, alkalis and polar and medium polar solvents. Hydrogen peroxide, which is the active element of PDM, is a polar solvent with distinctive dipole properties. Its molecules are more associated with water than water. Polar character also shows lower alcohols. Butyl alcohol is one of the polar protic solvents. Due to the polar nature of most present compounds and the presence of sodium hydroxide in the test decontamination mixture, it is believed that this is the main reason for the unaltered protective properties of the tested insulating protective film. Minimal changes that occurred in the space between the tested insulated foil and the seam coated with the polymeric coating can be attributed to the organic component of the PDM. The obtained results show that the destructive effects of non-polar solvents have been suppressed at the detriment of the polarity of hydrogen peroxide.

Nowadays, the CAF CCs management challenges representatives from the Military Research institute, State enterprise and the NBC Defence Institute of the University of Defence to think up solving problems with current decontamination mixtures in all aspects of their usage. All prepared activities are performed in the cooperation with the $31^{\text {st }}$ CBRN regiment. In current time some directions of either development of new barrier materials which would be more resistant against the effects od decontamination mixtures or rationalization of the portfolio of used decontamination mixtures are under the interests of responsible managers and commanders.

\section{References}

[1] Otrrísal, Pavel. Perception of security threats in the area of CBRN - history and challenges (in Czech). Vojenské rozhledy, 2013, roč. XXII (LIV.), č. 1, s. 46-64. ISSN 1210-3292.

[2] Otrísal, Pavel. Current Perception of possible Misuse of WMDS and TICS in the Czech Republic' Security-strategic Documents in relation to Czech Armed Forces Chemical Corps Specialists' Protection (in Czech). In Zborník prispevkov zo VII. vedeckej konferencie doktorandov a mladých vedeckých pracovníkov s medzinárodnou účastou „INTERPOLIS'10“. Editoři J. Cintula, J. Janičinová, I. Ondrušková. Bánská Bystrica : UMB, Fakulta politických vied a medzinárodných vzt’ahov, 25.11.2010, s. 82. ISBN 978-80-557-0155-4. 
[3] Otrrísal, Pavel. Perception of Security Threats in the CBRN Sphere: History and Challenges (in Czech). Vojenské rozhledy, 2013, roč. XXII (LIV.), č. 3, s. 67-75. ISSN 1210-3292.

[4] Otř́saL, Pavel; Melichařík, Zdeněk. The Czech Armed Forces Chemical Corps specialists' protection in relation to Security Threats and their Impacts on some Trends of Decontamination Development. In Conference Proceedings 3 "Applied Technical Sciences and Advanced Military Technologies of the $21^{\text {th }}$ International Conference "The Knowledge-Based Organization". Sibiu : "Nicolae Balcescu" Land Forces Academy, 11.-13.6.2015, s. 219-224. ISSN 1843-6722.

[5] Otř́sal, Pavel. Permeation of Toxic Industrial Materials through ruber materials (in Czech). [Dissertation work]. Vyškov : Univerzita obrany v Brně, Ústav ochrany proti zbraním hromadného ničení, 2012. 303 s. leader of the disertation work Stanislav Florus.

[6] Otřísal, Pavel; Florus, Stanislav; Obšel, Vladimír. Breakthrough Time of the Fabric coated with Butyl-rubber Polymer Mixture and its Relationship to the Chemical Structure of selected Toxic Industrial Chemicals. In Proceedings from $31^{\text {st }}$ International Symposium "Industrial Toxicology 2011“. Editor J. Babjaková. Bratislava : Slovenská spoločnost' priemyselnej chémie, 15.-17.6.2011, s. 24-35. ISBN 978-80-88973-72-0.

[7] Florus, Stanislav; Otrrísal, Pavel. The Resistance of Isolative Protective Folio for Specialists' Protection against Selected Chlorinated Hydrocarbons (in Czech). In Sborník př́spěvků z XII. ročníku mezinárodní konference „Ochrana obyvatelstva DEKONTAM 2013 “. Editor M. Šenovský. [CD-ROM]. Ostrava : Vysoká škola báňská Technická univerzita. Sdružení požárního a bezpečnostního inženýrství, 29.-30.1.2013, s. 36-39. ISBN 978-80-7385-122-4. ISSN 1803-7372.

[8] Otř́sal, Pavel; Florus, Stanislav. Destructive Influences of Selected Acids on Isolative Protective Folio of Specialists' Garments (in Czech). In Sborník př́spěvků z XII. ročníku mezinárodní konference „Ochrana obyvatelstva - DEKONTAM 2013“. Editor M. Šenovský. [CD-ROM]. Ostrava : Vysoká škola báňská - Technická univerzita. Sdružení požárního a bezpečnostního inženýrství, 29.-30.1.2013, p. 110-113. ISBN 978-80-7385-122-4. ISSN 1803-7372.

[9] Methodology of VOP-026 Šternberk. Division of VTÚO Brno. MIKROTEST 231301 "Set of breakthrough time of protective materials contaminated with drops and gases of sulfur mustard in static conditions (in Czech).

[10] Halámek, Emil, Kobliha, Zbyněk, Pitschmann, Vladimír. Analysis of chemical warfare agents (in Czech). Vyškov: ÚOPZHN UO Brno, 2007. 143 p. ISBN 978-80-7231-2580.

[11] Mcmurry, John. Organická chemie. (in Czech). Vydání první. Brno: Vysoké učení technické v Brně, nakladatelství VUTIUM, 2015. xix, 1178 stran. Překlady vysokoškolských učebnic; svazek 5. ISBN 978-80-214-4769-1.

[12] Matoušek, Jiř́i. Chemical weapons, chemical warfare agents. Prague: State Office for Nuclear Safety, (C2008. 53 s. ISBN 978-80-7385-041-8.

[13] Otř́sal, Pavel; Florus, Stanislav. Some aspects of 1,6-dichlorohexane usage as a spare test chemical for sulfur mustard in the branch of individual protection. (in Czech). In Zborník prednášok z 32. vedeckého sympózia "Priemyselná toxikológia 2012 “. Editor J. Babjaková. Bratislava : Slovenská technická univerzita v Bratislave, 20.-22.6.2012, p. 81-89. ISBN 978-80-227-3722-7. 
[14] Melichařík, Zdeněk; Otřísal, Pavel; Florus, Stanislav. The Influence of Decontamination Mixture of ODS-4 on Chemical Resistance of the Garments for Body Surface Isolative Protection of the Czech Armed Forces Chemical Corps Specialists. In Conference Proceedings 3 "Applied Technical Sciences and Advanced Military Technologies" of the $22^{\text {th }}$ International Conference "The Knowledge-Based Organization". [CD-ROM]. Sibiu : "Nicolae Balcescu" Land Forces Academy, 9.-11.6.2016, s. 159-166. ISSN 1843-682X. ISBN 978-973-153-247-9.

[15] Otř́sal, Pavel; Florus, Stanislav; Melichařík, Zdeněk. Chemical Resistance of Textile with a Butyl-rubber Polymeric Mixture against Decontamination mixture on the base of Chlorinated Aliphatic and Aromatic Hydrocarbons. In Conference Proceedings 3 "Applied Technical Sciences and Advanced Military Technologies" of the $23^{\text {rd }}$ International Conference "The Knowledge-Based Organization". [USB-DISK]. Sibiu : "Nicolae Balcescu" Land Forces Academy, 15.-17.6.2017, s. 234-242. ISSN 1843682X. ISBN 978-973-153-275-2. 